\title{
EGYÉNI KÜLÖNBSÉGEK AZ ALKOTÓ GONDOLKODÁSBAN: PSZICHÓZIS AZ ADAPTÍV MÜKÖDÉSBEN?*
}

\author{
POLNER BERTALAN ${ }^{1,2}$ - KÉRI SZABOLCS ${ }^{1,2,3}$ \\ ${ }^{1}$ Budapesti Műszaki és Gazdaságtudományi Egyetem, Kognitív Tudományi Tanszék \\ ${ }^{2}$ Nyírő Gyula Kórház - Országos Pszichiátriai és Addiktológiai Intézet \\ ${ }^{3}$ Szegedi Tudományegyetem, Élettani Intézet \\ E-mail: bpolner@cogsci.bme.hu; szkeri@cogsci.bme.hu
}

Beérkezett: 2014. december 02. - Elfogadva: 2015. március 23.

Célkitűzés: A kreativitás összefüggést mutat a pszichotikus zavarok és a normalitás közötti átmenettel. A pszichózis spektrumon a szkizofrénia pozitív, negatív, dezorganizált és affektív tüneteire emlékeztetó személyiségjegyek, a szkizotípiás vonások eltéréseit találjuk, melyek egészséges személyeknél összefüggést mutatnak az alkotókészséggel és az alkotó tevékenységekkel. Hogyan magyarázhatóak az összefüggések az alapvetö megismerési folyamatok szintjén? Mely további egyéni különbségek relevánsak a kreativitás kérdésében?

Módszertan: Az áttekintésben olyan tanulmányokat dolgoztunk fel, melyek a kreativitást a pszichózis spektrum, illetve a személyiségvonások, kognitív képességek és társas tényezök mentén vizsgálták. Emellett szemléztünk a kérdéskör neurális oldalát célzó tanulmányokat is.

Eredmények: Bizonyos, az átmenetre jellemzö neurokognitív vonások, mint a csökkent latens gátlás, az atipikus mintázatészlelés, valamint a szokatlan jelentöségtulajdonítás, köthetik a kreativitást a szkizotípia területéhez. Ezen funkciók mindegyikében a dopaminerg rendszerek érintettsége feltételezhetö. A kreativitást a pszichotikusszerü jelenségekhez kapcsoló kutatások mellett az empirikus szakirodalom jelentös része hangsúlyozza, hogy a nyitottság, a magas intelligencia vagy a jól müködö végrehajtó funkciók rendkivül fontosak a kreatív gondolkodásban és teljesítményben. További, az alkotótevékenységet fokozó tényezönek mutatkozik a társas támogatás.

Következtetések: Az áttekintett irodalom alapján a szkizotípia neurokognitív szerkezete adaptív tényezókkel társulva a kreativitás szolgálatába állitható. Az irodalom szintézise felveti a kérdést, hogy miként viszonyul egymáshoz az adaptív szkizotípia és a nyitottság felépitése és fejlödése.

Kulcsszavak: kreativitás, pszichózis, nyitottság, dopamin, intelligencia

* A munka a Nemzeti Agykutatási Program (KTIA_NAP_13-2014-0020) támogatásával készült el. 
A kreativitás és a mentális zavarok együttjárásáról szinte regénybe illő elképzelések élnek a laikus és a tudományos köztudatban (JUNG, 2014). A kapcsolódás illusztrációjaként visszatérően hallhatunk híres mủvészek és tudósok vélt vagy valós lelki zavarairól (DIETRICH, 2014). Mit üzennek az empirikus vizsgálatok a kreativitás és a mentális zavarok között feltételezett összefüggésről, különös tekintettel a legsúlyosabbnak tekintett pszichózisokra, amikor az egyén és a konszenzusokon alapuló valóság közötti kapcsolat megszakad?

A kreativitás alacsonyabb szintű kognitív folyamatok sokaságát foglalja magában (ABraham, 2014; DieTrich, 2004). Talán komplexitásából is adódik, hogy nincs egységesen elfogadott meghatározása, a kutatásokat olvasva rengeteg kreativitásdefinícióval szembesülünk (a kérdés történeti áttekintését adja RUNCO és JAEGER, 2012). Bár az elméleti (DIETRICH, 2004, 2014) és módszertani sokszínűség (Arden, Chavez, Grazioplene és Jung, 2010; Dietrich és Kanso, 2010) nehezíti a tisztánlátást, a kutatók többnyire egyetértenek abban, hogy a kreativitás egy kettősség mentén ragadható meg. E konszenzus értelmében a kreatív aktus egy az adott társas közegben újnak, eredetinek, és egyben hasznosnak számító termék létrehozása, mely a képességek, a folyamatok és a környezet kölcsönhatásai által valósul meg (PléH, 2010; Plucker, Beghetto és Dow, 2004; Sternberg, 2001). Figyelemre méltó, hogy a szabályozottság és a spontaneitás egyensúlyozása, mint kulcskérdés, a pszichoanalitikus kreativitáselméletekben is visszaköszön (KÖVÁRY, 2012).

A kreativitás rendszerszemléletű megközelítéseinek fő üzenete, hogy az alkotótevékenység megértéséhez rendkívül fontos az élettörténet, illetve a társas és a kulturális környezet figyelembevétele (Csíkszentminályi, 2008; Pléh, 2010; SimONTON, 2000). A társas tényezők közvetve jelennek meg AMABILE (1983) elméletében, aki a kreativitás fő összetevőiként a belső motivációt, a szakértelmet, valamint a kreatív gondolkodási készségeket sorolta fel. A szociális közeg a belső motiváció serkentésén vagy elnyomásán keresztül befolyásolhatja az alkotótevékenységet (Amabile, Conti, Coon, Lazenby és Herron, 1996). Kaufman és BEGHETTO (2009) a kreativitás szintjeinek elkülönítését javasolták: elméletükben megkülönbeztetik a tanulás során felbukkanó új és értelmes értelmezéseket (mini $\mathrm{C}$, mint creativity), a hétköznapi (kicsi $\mathrm{C}$ ) és a professzionális (pro C) téren megvalósított újításokat, valamint a kiemelkedően kreatív, hírnévhez vezető alkotásokat (nagy C). DiETRICH (2004) a kognitív és az érzelmi kreativitásra egy tartomány két végpontjaként tekintett. Bár az előbbi inkább a mérnöki-tudományos felfedezésekben érintett, az utóbbi pedig inkább a művészi alkotásban és a pszichoterápia alatt szerzett belátás folyamatában érvényesül, valószínű, hogy mindenféle kreatív tevékenység során a kognitív és érzelmi kreativitás eltérő arányban, de együttesen jut érvényre. 


\section{KREATIVITÁS ÉS LÉLEKTANI TERMÉSZETŰ EGYÉNI KÜLÖNBSÉGEK}

\section{Kreativitás a pszichózis spektrum kontextusában}

A kreativitás változatos mentális zavarok kapcsán felmerült már mint a lelki sérülékenység egy lehetséges kedvező „mellékhatása”. A fokozott alkotókészséget kapcsolatba hozták például a bipoláris hangulatzavarral (KYAGA és mtsai, 2011, 2013; Richards, Kinney, Lunde, Benet és Merzel, 1988; Simeonova, Chang, STRONG és KETTER, 2005) vagy a hiperaktivitás-figyelemzavarral (ABRAHAM, Windmann, Siefen, DAUm és GÜNTÜrkÜN, 2006; WhITE és SHAH, 2011), bár az összefüggések korántsem egyértelműek (például KYAGA és mtsai, 2013; WHITE és SHAH, 2006). A kreativitás burjánzása jellemzően a pszichiátriai betegek egészséges elsőfokú rokonainál érhető tetten (KYAGA és mtsai, 2011, 2013; RICHARDS és mtsai, 1988). A kreativitást a bipoláris hangulatzavarral, valamint az affektív temperamentummal összevetve elemző, kiterjedt szakirodalom bemutatása túlmutat jelen dolgozat keretein (például ANDREASEN, 1987; JANKA, 2006; MACCABE és mtsai, 2010; Nowakowska, Strong, Santosa, Wang és Ketter, 2005; Rihmer, GONDA és RiHMER, 2006; SCHLESINGER, 2009); áttekintésünkben a pszichózisok és a kreativitás kérdéskörei közötti szövevényes viszonyrendszer feltárására fogunk törekedni.

A kiteljesedett pszichotikus zavar nem segíti a kreativitás kibontakozását, ellenben a szkizofréniával vagy szkizoaffektív zavarral diagnosztizáltak egészséges elsőfokú rokonai gyakrabban emelkednek ki kreativitásukkal a populációból, mint azok, akiknek közeli rokonsági körében nem fordult elő ilyen megbetegedés (KARLSSON, 1970; KYAGA és mtsai, 2011, 2013). A több tízezres nagyságrendű mintákat alkalmazó kutatások korlátja volt (KYAGA és mtsai, 2011, 2013), hogy a kreativitást nem a tényleges teljesítmény, hanem a foglalkozási kategória mentén vizsgálták. Mégis, talán a családi közelség a pszichotikus zavarokhoz, amennyiben nem társul a mentális egészség jelentős romlásával, segítheti a szokatlan és egyben jól használható ötletek kigondolását és megvalósítását.

A klinikai pszichózist idéző fenotípusok felbukkanhatnak az egészséges populációban is. A szakirodalom ezt a jelenségkört a pszichózis hajlam, a pszichotikus élmények, a szkizotípiás vonások vagy a kiemelt kockázati állapot (,ultra-highrisk") fogalmak mentén tárgyalja. A szubklinikus megjelenési formák figyelemre méltó módon a szkizofréniának nem csupán a feltételezett genetikai, de változatos környezeti kockázati tényezőivel is összefüggést mutatnak (áttekintésért lásd EtTinger, Meyhofer, Steffens, Wagner és Koutsouleris, 2014; Kéri, 2013; M. T. Nelson, Seal, Pantelis és Phillips, 2013; van Os, Linscott, MyinGermeys, DelesPaul és KRABbendaM, 2008). A szkizofréniára jellemző kognitív deficit általában enyhébb formában kimutatható a szubklinikus megjelenési formák esetében, bár néhány szkizofréniában sérült megismerési komponens nem látszik érintettnek (ETTINGER és mtsai, 2014; HORI és mtsai, 2014; M. T. NELSON és mtsai, 2013). A rendelkezésre álló funkcionális és strukturális képalkotó vizsgálatok tovább árnyalják a képet: a finom, szkizofréniával analóg károsodásokon túl feltételezhetőek kompenzációs neurális folyamatok, melyek határt húzhatnak a 
patológia és az alkalmazkodás között (ETTINGER és mtsai, 2014; M. T. NELSON és mtsai, 2013). Változatos mérési szintekről származó adatok támogatják a szkizofrénia dimenzionális megközelítését (ETTINGER és mtsai, 2014; LAURENS, HobBS, Sunderland, Green és Mould, 2012; Markon, ChMielewski és Miller, 2011; M. T. Nelson és mtsai, 2013; RAWlingS, Williams, Haslam és Claridge, 2008a, 2008b), miszerint az egészséges populációban fellelhető pszichotikusszerű élmények és vonások valós átmenetet képeznek a normalitás és a pszichotikus zavarok között (de lásd még a kategorikus megközelítés mellett BEAUCHAINE, LENZENWEGER és WALLER, 2008).

Egy 45 tanulmányt összegző metaanalízis a kreativitás, valamint a pozitív (a szkizofrénia pozitív tüneteire emlékeztető vonások) és a negatív szkizotípiás jegyek (a szkizofrénia negatív tüneteivel párhuzamos vonások) ellentétes irányú és gyenge összefüggéseire hívta fel a figyelmet (ACAR és SEN, 2013). A metaelemzésbe bevont kutatások a kreativitást változatos úton mérték: egyes tanulmányok teljesítményteszteket (például divergens gondolkodás, asszociációs vagy mentális képzeleti tesztek), mások önjellemző skálákat (kreatív jellemvonásokat, kreatív szabadidős tevékenységeket vagy kiemelkedő kreatív teljesítményeket rögzítő kérdőívek) használtak. Az elemzés végkövetkeztetése szerint a pozitív és impulzív szkizotípiás jegyek tipikusan gyenge, pozitív kapcsolatot, míg a dezorganizált és negatív szkizotípiás vonások inkább gyenge, negatív összefüggést mutatnak az alkotókészséggel, annak mérési módjától függetlenül. Valamivel erősebb, de szintén gyenge összefüggést figyeltek meg a szkizotípia és a kreativitás között a művészet területén az általános kreativitáshoz képest, illetve a kiemelkedő alkotók körében a nem kiemelkedő személyekhez képest.

A már említett divergens gondolkodás teszteket gyakran alkalmazzák a kreatív potenciál felmérésére (RUNCO és ACAR, 2012). E tesztek jellemzően egy sokféleképpen megközelíthető probléma megoldását kérik a vizsgálati személytől, például hogy fejezzen be egy néhány vonásból álló megkezdett rajzot vagy sorolja fel minél több felhasználási lehetőségét egy hétköznapi tárgynak. Az ötletek szokatlanságának és újszerűségének tendenciáját a szkizotípia pozitív, affektív és aszociális vetületéhez kötötték vizsgálatok (CLARIDGE és BLAKEY, 2009; ZABELINA, CONDON és BEEMAN, 2014), míg az ötletek mennyisége a pozitív és dezorganizált szkizotípiás vonásokkal mutatott egyenes összefüggést (FOLLEY és PARK, 2005). A kreativitás megnyilvánulása az önjellemzésben, a személyiségben és a tevékenységekben a pozitív és impulzív szkizotípiás jegyekhez egyenesen, míg a dezorganizált jegyekhez fordítottan aránylott (BATEY és FURNHAM, 2008). Továbbá dokumentálták a kreativitáshoz kapcsolódó hiedelmek, kiemelten a tudattalan folyamatokba vetett hit együttjárását a pozitív és dezorganizált szkizotípiás jegyekkel (ClaRidge és Blakey, 2009).

A pozitív szkizotípiás jegyek gazdagíthatják a művészi alkotás élményvilágát: egy kutatás szerint, melyben 100 művész vett részt, a pszichotikusszerű vonások összefüggtek az alkotás közben érzett különleges, izgalmas és élvezetes élményekkel, valamint az alkotásba való bevonódással (B. Nelson és RAWLings, 2010). Ez magyarázhatja azt az eredményt, miszerint 35 , kiemelkedően kreatív képzőművész és zenész körében a pozitív szkizotípia magasabb szintje található, mint emi- 
nens biológus és fizikus kutatók, valamint matematikusok ugyanekkora méretú csoportjában (RAWLINGS és LOCARNINI, 2008). Így valószínűnek tünik, hogy a szokatlan élményeket inkább a művészi, mint a tudományos alkotómunkában lehet hasznosítani. Ugyanezen vizsgálatban a művészeti és a tudományos kreativitás elkülönülni látszott az asszociatív gondolkodás mintázatában: a művészekre a szokatlan képzettársítás, a matematikusokra és a fizikusokra inkább az ellentéteket összekötő gondolkodás volt jellemző egy szóasszociációs teszt alapján (RAWLINGS és LOCARNINI, 2008). A szkizotípia evolúciós szempontból adaptív lehet NETTLE és CLEGG (2006) tanulmánya szerint. Hobbi, elkötelezett és professzionális költők és képzőművészek (186 fő), valamint semmiféle kreatív tevékenységet nem végző személyek (239 fö) vettek részt vizsgálatukban. A hallucináció- és téveszmeszerü élmények pozitív kapcsolatot mutattak a kreatív aktivitás mértékével, az pedig pozitívan korrelált a szexpartnerek számával. Az impulzív-aszociális vonások az alkotótevékenységgel nem mutattak összefüggést, viszont egyenesen aránylottak a szexpartnerek mennyiségéhez.

\section{Kreativitás az adaptív személyiségvonások és képességek kontextusában}

Több tanulmány kísérelte meg a kreatív képességeket és teljesítményeket az adaptív személyiségműködés kontextusában ábrázolni. A Nagy Ötök (Big Five) személyiségmodell fogalmi keretei között dolgozó vizsgálatok szerint a kreativitás különféle mérései (divergens gondolkodás gördülékenysége és eredetisége, önjellemzés, illetve kreatív tevékenységek és teljesítmény) jellemzően fokozott nyitottsággal (KinG, Walker és Broyles, 1996; Miller és TAL, 2007; Silvia és mtsai, 2008) és extraverzióval (Furnham és BACHTIAR, 2008; FurNhAM, BATEY, ANAND és MANFIELD, 2008; KING és mtsai, 1996), illetve esetenként alacsonyabb barátságossággal (FURNHAM és mtsai, 2008; KING és mtsai, 1996) vagy lelkiismeretességgel társulnak (SILviA és mtsai, 2008). A nyitottságot és az extraverziót tömörítő plaszticitás szupervonás a kreativitás változatos mutatóival (például divergens gondolkodás, kreatív hobbik és teljesítmények, gyakorlatias és empatikus kreativitás) markáns pozitív kapcsolatokat mutatott (SILvia, Nusbaum, BerG, MARTin és O'CONNOR, 2009). Ezzel szemben a lelkiismeretességet, a barátságosságot és a neuroticizmust (fordított) sủrítő stabilitás szupervonás a divergens gondolkodással (SILVIA és mtsai, 2008) és a való életben megnyilvánuló kreativitással közepes negatív, míg a tudományos-matematikai és a társas-empatikus kreativitással szerény pozitív összefüggésben álltt (SILVIA és mtsai, 2009).

A mentális zavarok diagnosztikájának fejlesztése során újult lendületet kapott a törekvés a Nagy Ötök és a személyiségpatológia dimenziói, köztük a szkizotípia, integrálására (KRUEGER és MARKON, 2014). Ötfaktoros megoldással a nyitottság/intellektus és a különcség, valamint a szokatlan észlelések és hiedelmek egy latens változóra sorolódtak egyetemi hallgatókból álló mintákon (DE FRUYT és mtsai, 2013; THOMAS és mtsai, 2013). Bár alacsonyabb töltéssel, de ugyanezen a dimenzión jelentkezett a kockázatvállalás (DE FrUYT és mtsai, 2013) és az impulzivitás (Thomas és mtsai, 2013), illeszkedve azon elképzeléshez, miszerint az affektív 
diszreguláció szerves összetevője a szkizotípia jelenségkörének (MASON és CLARIDGE, 2006). A nyitottság/intellektus vonásegyüttes pontos helye a pszichopatológia dimenzionális modelljében a nyitottság és az intellektus közös varianciájának statisztikai kontrollálása után nyilvánult meg. Ekkor a nyitottság pozitív, míg az intellektus vonás negatív kapcsolatot mutatott a szkizotípiás vonásokkal egészséges felnőttek (DeYoung, GrazioPlene és PETERson, 2012) és pszichiátriai betegek körében is (Chmielewski, Bagby, MARKon, Ring és Ryder, 2014), valószínűsítve, hogy a szkizotípia a nyitottság patológiás pólusának tekinthető.

Számos kutatás hangsúlyozta, hogy az alkotó gondolkodáshoz és tevékenységhez bizonyos személyiségvonások mellett magas intelligencia és jól fejlett kognitív kontroll is szükséges (áttekintésért lásd BARRON és HARRINGTON, 1981; BATEY és FURNHAM, 2006). Lendületet adott a kreativitás kutatásának a 20. század közepén Guilford kritikai észrevétele, miszerint az intelligenciatesztek nem érzékenyek bizonyos, a kreativitáshoz szükséges adottságokra (GUILFORD, 1950). Klasszikus vizsgálatok szerint az intelligencia egy bizonyos küszöbig (IQ 120) együttjár a kreatív gondolkodási képességekkel, afelett pedig függetlenedik az IQ és az alkotókészség (például BARKÓCZI, OLÁH és ZÉTÉNYI, 1973; GETZELS és JACKSON, 1962). A divergens gondolkodás gördülékenységére (azaz az ötletek mennyiségére) és eredetiségére nézve megerősítette ezt a mintázatot egy vizsgálat, melyben közel háromszáz egészséges felnőttet vontak be. Ellenben a való életben elért kreatív teljesítmény és az IQ között töretlen egyenes összefüggést mutattak ki (JAUK, BENEDEK, DUNST és Neubauer, 2013). Az intelligencia szerepet játszhat még abban, hogy a kreatív gondolatok és cselekvések mások által is elismert teljesítményekhez vezessenek. Ugyanezen vizsgálati mintában az alkotótevékenységek gyakorisága a nyitottsággal és a divergens gondolkodással mutatott kapcsolatot, valamint összefüggésben állt a kreatív teljesítményekkel is. Az általános intelligencia egyrészt közvetlen kapcsolatban állt a kreatív teljesítményekkel, másrészt moderálta a kreatív tevékenységek és teljesítmények közötti összefüggést (JAUK, BENEDEK és NEUbAUER, 2013).

Az általános intelligenciának vajon mely komponensei igazán fontosak az alkotáshoz? AMABILE összetevő-elmélete (1983) alapján feltételezhető, hogy a kreativitáshoz az összefüggések felismerésének képességére, valamint a szerzett ismeretekre-készségekre (fluid, illetve kristályos intelligencia; CATTELL, 1987) egyaránt szükség lehet. A divergens gondolkodás eredetiségének intellektuális hátterének felderítésére számos vizsgálat törekedett. Körülbelül párszáz fős nagyságrendű, egyetemi hallgatókból álló mintákon végzett elemzések szerint a kiterjedt előhívási képesség (Beaty, Silvia, Nusbaum, Jauk és Benedek, 2014; Silvia, Beaty és NuSBAUM, 2013), a kristályos intelligencia (BEATY és mtsai, 2014) és a távoli szemantikus asszociációk (BEATY és mtsai, 2014; BENEDEK és NEubauer, 2013) mind hozzájárulhatnak az originális ötletekhez. Újabb adatok szerint a kreatív divergens gondolkodás és a fluid intelligencia korrelációját nagyban a frissítési végrehajtó funkció és a nyitottság személyiségvonás magyarázza. Az eredeti és értelmes ötletek hátterében az automatikus válaszok gátlása és a reprezentációk frissítése bizonyultak lényeges végrehajtó folyamatoknak egy több mint kétszáz résztvevővel futtatott vizsgálatban (Benedek, Jauk, Sommer, Arendasy és Neubauer, 2014). 
Egy ötven egyetemi hallgatóval végzett vizsgálat izgalmas eredményre vezetett: az eredeti divergens gondolkodáshoz és a kreatív teljesítményekhez nem a domináns válaszok gátlásának abszolút erőssége, hanem alkalmazásának rugalmas szabályzása járul hozzá (ZABELINA és ROBINSON, 2010). Vagyis azok a személyek, akiknél nagymértékủ gátlást lehetett mérni akkor, amikor várhatóan a nem domináns válasz volt a helyes, de kisebb gátlást, amikor nem számítottak arra, hogy szabályozniuk kell reakciójukat, nagyobb kreatív potenciállal és több kreatív teljesítménnyel rendelkeztek. Egy további tanulmányban, mely szintén félszáz egyetemi hallgatót vizsgált, az előhívás kiváltotta felejtési kísérletben mért emlékezeti gátlás fordított kapcsolatot mutatott az ötletelés eredetiségével és gördülékenységével (LiN és LiEN, 2013). Tehát akiknél gyengébb volt a nem gyakorolt emléknyomokra irányuló elnyomás, azok több és egyedibb ötlettel álltak elő a divergens gondolkodási teszten.

Mindezek ismeretében érdemes kitérnünk arra, hogy számos metaanalitikus tanulmány pszichózisban gyenge kognitív kontrollról adott számot (például Dickinson, Ramsey és GOLD, 2007; Lee és Park, 2005; Mesholam-Gately, GIUliano, GOFF, FARAONe és SEIDMAN, 2009), illetve a pszichotikus betegek körülbelül kétharmadára alacsony intelligencia jellemző (DERKS és mtsai, 2012; Dickinson és mtsai, 2007; MesholaM-GATElY és mtsai, 2009). Valószínűsíthető, hogy magas intelligencia és ép kognitív kontroll hiányában a pszichózis azon sajátosságai, melyek adaptív tényezők társaságában kedveznek a kreativitásnak, egyéb maladaptív hatások mellett inkább rontják a társas készségeket és hátráltatják a mindennapi működést (DERKS és mtsai, 2012; FETT és mtsai, 2011).

\section{NEURÁLIS ALAPOK: A DOPAMINERG RENDSZEREK ELTÉRÉSEI}

Milyen idegtudományi adatok állnak rendelkezésre az alkotókészség egyéni különbségeit illetően? Az elmúlt évtizedben a témában robbanásszerűen jelentek meg közlemények (összefoglalóért lásd ARDEN és mtsai, 2010; DIETRICH és KANSO, 2010), ezért rövid áttekintésünkben a pszichózis elméleteiben központi szerepet játszó dopaminerg rendszerekre fogunk szorítkozni (HOWES és KAPUR, 2009).

Egy közel kétszáz egyetemista bevonásával készített feltáró viselkedésgenetikai kutatás a DRD4 dopamin receptor gént hozta összefüggésbe a figurális és verbális divergens gondolkodással (MAYSELESS, UZEFovsky, SHALEv, EbSTEIN és SHAMAYTSOORY, 2013). A vizsgálat eredményei szerint a gyengébb válaszgátlással összefüggésbe hozott DRD4 variáns (például CONGDON, LESCH és CANLI, 2008) társult kevesebb kreatív potenciállal. Egy másik feltáró tanulmány pedig a dopaminerg és a szerotonerg (REUTER, ROTH, HOLVE és HENNIG, 2006) rendszerekhez köthető gének polimorfizmusait jelölte meg a divergens gondolkodás eltéréseinek potenciális okozóiként. Ez a kutatás közel száz, az átlagosnál magasabb intelligenciájú egyetemistánál (átlag IQ 115) képi, szóbeli és matematikai problémák megoldása során mérte a képzeletgazdag, több szempontú gondolkodási képességet. Az ered- 
mények szerint a DRD2 dopamin receptor gén alacsonyabb D2 receptorsűrűséggel társított variánsa (RITCHIE és NOBLE, 2003) kapcsolódott a fokozott kreatív potenciálhoz.

Ezzel összecsengő eredményt hozott az a kutatás, mely egy 14 fős, 59 éves átlagéletkorú mintán pozitron emissziós tomográfia (PET) segítségével mérte a D2 dopaminreceptor-sűrűséget. A talamusz receptorsűrűsége negatív együttjárást mutatott az ötletek mennyiségével a szóbeli, rajzolási és matematikai divergens gondolkodási teszteken. A striátumban és a frontális kéregben nem volt szignifikáns kapcsolat a D2 receptorsűrűség és a kreatív potenciál között. Lehetséges, hogy a talamikus kapuzástól függően csökken a prefrontális kérgi jel-zaj arány, ami kedvez a kreatív gondolattársításoknak (DE MANZANO, CERvENKA, KARABANOV, FARDE és ULLÉN, 2010). Egy másik kutatócsoport strukturális mágneses rezonancia képalkotást (magnetic resonance imaging, MRI) bevetve agyi régiók térfogatát korreláltatta egy összesített divergens gondolkodási indexszel, mely magában foglalta az ötletek mennyiségét, eredetiségét, kidolgozottságát és változatosságát. A vizsgálatban részt vevő félszáz fiatal felnőttnek (átlagéletkoruk 22 év) minél több válasszal kellett előállniuk olyan kérdésekre, mint például „Mire lehet használni egy újságot az olvasáson túl?”, vagy „Mi jellemez egy jó TV-készüléket?”, illetve „Mi lenne, ha a világ összes egere eltűnne?”. A dopaminerg rendszerekhez tartozó középagyi, kéreg alatti és kérgi területek térfogata pozitív kapcsolatban állt az összesített divergens gondolkodási indexszel (TAKEUCHI és mtsai, 2010). E néhány feltáró vizsgálat eredményei kétségtelenül izgalmasak, de vajon milyen alapvető kognitív folyamatok által kapcsolódhatnak a kreativitás jelenségköréhez a dopaminerg rendszerek?

\section{Dopaminfüggő alapvető kognitív folyamatok és egyéni különbségeik}

A dopaminerg rendszerek gyógyszeres manipulációjára a latens gátlás érzékenységet mutat (LubOw, 2005; SWERdLow és mtsai, 2003; WEINER és ARAD, 2009). Latens gátlás alatt azt a jelenséget értjük, amikor egy inger ismételt, következmények nélküli bemutatásának hatására később ezen ingerrel nehezebben történik meg az asszociatív tanulás. A latens gátlás a feldolgozás hangsúlyát a régi és nem fontos ingerek felől az újak irányába tolja el, ezáltal szorosan összefonódik a szelektív figyelem működésével (LuBOw, 2005). A pozitív szkizotípiás jegyekkel a latens gátlás jellemzően fordított összefüggésben áll (BURCH, HeMSLEY, PAVELIS és Corr, 2006; Granger, Prados és Young, 2012; Tsakanikos, SverdrupTHYGENSON és REED, 2003), bár a hatások gyengék és nem mindig mutathatóak ki (például Evans, GraY és SNOWDEN, 2007). További vizsgálatok arra utalnak, hogy magas szkizotípiás személyeknél a latens gátlás kiépülése ép, azonban kifejeződése abnormális (TSAKANIKOS és REED, 2004). Mások felvetették, hogy a hiányos latens gátlás elsősorban a szorongással és nem a szkizotípiás jegyekkel áll összefüggésben (BRAUNSTEIN-BERCOVITZ, RAMMSAYER, GibBONS és LUBOW, 2002).

A dopaminerg neurotranszmisszió kitüntetett jelentőséggel bír továbbá a predikciós hiba jelzésében (SCHULTZ, 2000), mely a várt és a tényleges események 
közötti eltérést kódolja (FIORILlo, TOBLer és Schultz, 2003). Az emberi striátumban mért predikciós hiba érzékeny a dopaminerg rendszerek gyógyszeres manipulációjára (Pessiglione, Seymour, Flandin, Dolan és Frith, 2006). A neurális számítások szintjén a predikciós hiba összesítve jelzi egy esemény váratlanságát és jelentőségét (SMITH, LI, BECKER és KAPUR, 2006). A predikciós hiba részt vesz a belső modellek és a külvilág kölcsönhatásainak szabályzásában: ezen folyamat révén formálják a tapasztaltak a világról alkotott képet (CARHART-HARRIS és FRISTON, 2010; FRISTON, 2009). A rendszer zavara esetén a belső reprezentációk és a világ összhangja megbomlik: a személy a valóságtól „elcsúszik”, hallucinációk és téveszmék bukkannak fel az élményvilágban (FLETCHER és FrITH, 2009). Egészséges személyeknél a mágikus gondolkodással a striátumban mért predikciós hiba együttjárt egy vizsgálatban. A téveszmeszerű gondolatok keltette szorongás viszont inkább a jobb dorzolaterális prefrontális kéregben mért predikciós hibával állt összefüggésben (CORLETT és FLETCHER, 2012), hasonlóan a klinikai pszichózis esetén megfigyeltekhez (CORLETT és mtsai, 2007). Az eredmények arra utalnak, hogy a mentális egészséget károsító delúzió és az „egészséges” szkizotípiás élmények neurális lenyomata különbözik (CORLETT és FLETCHER, 2012). Egy izgalmas nyitott kérdés, hogy a predikciós hiba eltérései miként kapcsolódnak az alkotó gondolkodáshoz.

Az elvárások és tapasztalatok összehangolásának anomáliáit tükrözheti, hogy magas pozitív szkizotípiás személyek hajlamosak értelmet észlelni véletlen szerveződésű, értelmetlen ingerekben (DEYOUNG és mtsai, 2012). A téveszme- és/vagy hallucinációszerủ élményekről beszámoló egészséges személyek fogékonyak arra, hogy értelmetlen karakterláncokban értelmes szavakat észleljenek (GRANT, BALSer, Munk, Linder és Hennig, 2014; Reed és mtsai, 2008; Tsakanikos, 2006; TSAKANIKOS és REED, 2005), háromszögek véletlenszerủ mozgását szabályosnak ítéljék és a háromszögeknek szándékot tulajdonítsanak (FYFE, WILLIAMS, MASON és PICKuP, 2008), vagy vizuális (SimmONDS-MOORE, 2014) és auditoros zajban értelmes észleleteket tapasztaljanak meg (GALDOS és mtsai, 2011; SimmONDSMOORE, 2014). Ezek a tendenciák kedvezőtlen esetben pszichotikus tünetekhez vezethetnek (például GALDOS és mtsai, 2011), de akár utat nyithatnak kreatív meglátásoknak: aki képes rendszert látni abban, ami mások számára véletlenszerű zaj (DEYOUnG és mtsai, 2012; Fyfe és mtsai, 2008; GRANT és mtsai, 2014), az új összefüggéseket fedezhet fel (MEDNICK, 1962).

A pszichotikus tünetek hozadékai lehetnek a jelentőség nélküli információ sikertelen elnyomásának, majd az ebből fakadó önkényes képzettársításoknak (Howes és Kapur, 2009; B. Nelson, Whitford, Lavoie és Sass, 2014). A jelentőségtulajdonítás aberrációja nem korlátozódik a klinikai pszichózisokra, a szkizofréniaszerü szubklinikus jelenségekkel is összefüggést mutat (ROISER és mtsai, 2009; SCHMidT és RoISER, 2009). Parkinson-kórral diagnosztizált betegek dopamin agonista terápiája során az adaptív és aberráns jelentőségtulajdonítás egyaránt erősödést mutatott vizuális reakcióidő feladatban, ahol a helyes válaszadást jutalmazták. Az illuzórikus együttjárások önkényes kialakulása összefüggésben állt a hallucináció- és téveszmeszerủ élmények enyhe fokozódásával (NAGY és mtsai, 2012). A jelentőségtulajdonítás torzulásai nyomán a pszichózis spektrumon a 
konszenzuális értelmezések kevésbé jutnak érvényre, megzavarván az illeszkedést a fizikai és a társas környezethez (B. Nelson és mtsai, 2014). A kontextuális szabályzás szelídülése azonban segítheti a kreatív megoldást olyan esetekben, amikor a standard elvárások nem célravezetőek.

\section{Pszichotikusszerü neurokognitív vonások adaptíu konstellációkban támogatják a kreativitást}

Figyelemre méltó, hogy az adaptív személyiségvonások közül a szkizotípiához közel álló nyitottság (DEYOUNG és mtsai, 2012), illetve az extraverzió is alacsony latens gátlással társul (Peterson és CARson, 2000; Peterson, Smith és CARSON, 2002). A nyitottság egy tendenciát jelez arra, hogy az egyén szenzoros és absztrakt információt keressen, feldolgozzon és hasznosítson (DEYOUNG, 2014). Fokozott nyitottságú személyek dorzolaterális prefrontális kéregre érzékeny neuropszichológia tesztek szerint hatékonyabb kognitív kontrollal (DEYOUnG, PETERSON és HigGins, 2005), illetve magasabb verbális intelligenciával bírnak (DEYOUNG, Quilty, Peterson és GraY, 2014). A nyitottság egyéni különbségeit nemrég összefüggésbe hozták a prefrontális kéreg dopaminellátottságában központi szerepet játszó gének polimorfizmusaival (DEYoUnG és mtsai, 2011). Tehát a magas nyitottságban együttesen jelennek meg a való életben elért kreatív teljesítményhez szükséges tényezők, úgymint az alacsony latens gátlás és a magas intelligencia (KÉRI, 2011).

Egy friss kutatás rejtett profilelemzéssel adaptív és maladaptív magas szkizotípiás, illetve adaptív alacsony szkizotípiás csoportokat mutatott ki egészséges középkorú felnőttek körében (HORI és mtsai, 2014). Mindkét magas szkizotíp csoportban gyakoribbak voltak az észlelési és gondolkodási aberrációk. Az adaptív csoportnál az érzelemszabályozás, az önirányítottság, illetve a társas és a kognitív funkciók terén nem jelent meg az a finom károsodás, ami a maladaptív szkizotípiás csoportot jellemezte. Emellett kiugróan magas spiritualitás jellemezte az adaptív magas szkizotípiás csoportot. Az alkotó gondolkodás vizsgálatára sajnos nem terjedt ki ez a kutatás.

\section{ÖSSZEGZÉS}

\section{Zsenialitás vagy patológia?}

Izgalmas kérdés, hogy milyen tényezők határozzák meg, hogy a pszichotikusszerű vonások a fokozott alkotókészség vagy a mentális zavarok szolgálatában állnak. Jelentős szerepe lehet az egymással kölcsönhatásba lépő genetikai faktoroknak és fejlődési hatásoknak (ALEMANY és mtsai, 2014; vAN Os és mtsai, 2008), valamint a traumatikus eseményekkel való megbirkózás képességének, a rezilienciának (TAIT, BirCHWOOD és TROWER, 2004). Nem elhanyagolható továbbá a jó kognitív képességek, az adaptív személyiségtényezők és a spiritualitás hatása, amelyek lehetővé 
teszik a pszichotikusszerủ élmények biztonságos keretezését (HORI és mtsai, 2014; SCHOFIEld és ClARIDGE, 2007). A stresszorok fokozzák a pszichotikusszerű tünetek és a paranoid gondolatok átélésének valószínűségét, különösen azoknál, akiknél kifejezettek a pozitív szkizotípiás jegyek (BARRANTES-VIDAL, CHUn, MYINGERMEYS és KWAPIL, 2013). Képalkotó vizsgálatok érdekes módon a dopaminrendszer stresszre mutatott válaszkészségét a negatív szkizotípiás vonásokkal és a szkizofrénia hajlam egy biológiai markerével kapcsolták össze (SOLIMAN és mtsai, 2008, 2011). A társas támogatás segíthet a fejlődést adaptív mederben tartani (Domínguez-Martínez, Medina-Pradas, KwaPil és BarRantes-Vidal, 2014), fokozván egyúttal a kreativitás kibontakozását is (AMABile és PILlemer, 2012; KÉRI, 2011).

A szkizotípiára jellemző neurokognitív sajátosságok növelhetik a kreativitást, amennyiben olyan adaptív tényezők kísérik őket, mint a magas intelligencia, a fejlett kognitív kontroll vagy a jó társas készségek. Következésképp a kreativitás nem a patológiás, hanem elsősorban az egészséges lelki működés velejárójának tekinthető. A kreativitás kutatásában a kognitív idegtudományi megközelítés adta ismeretek értékesek, önmagukban azonban korlátozottan értelmezhetőek, tágabb - élettörténeti, társas, kulturális - kontextusba ágyazásuk izgalmas jövőbeni iránya lehet a kérdéskör vizsgálatának. Emellett a szkizotípia és a magas nyitottság felépítése és fejlődése közötti eltérések, illetve átfedések is tisztázásra várnak. Ezeknek ismeretében nem csupán a kreativitás és a mentális zavarok összetettségének mélyebb megértése válna lehetővé, de egyúttal akár a pszichózis megelőzése is új szempontokkal gazdagodhatna.

\section{IRODALOM}

ABraham, A. (2014). Creative thinking as orchestrated by semantic processing vs. cognitive control brain networks. Frontiers in Human Neuroscience, 8.

http://doi.org/10.3389/fnhum.2014.00095

Abraham, A., Windmann, S., Siefen, R., Daum, I., \& Güntürkün, O. (2006). Creative thinking in adolescents with attention deficit hyperactivity disorder (ADHD). Child Neuropsychology, 12(2), 111-123.

ACAR, S., \& SEN, S. (2013). A multilevel meta-analysis of the relationship between creativity and schizotypy. Psychology of Aesthetics, Creativity, and the Arts, 7(3), 214-228.

Alemany, S., Arias, B., Fatjó-Vilas, M., Villa, H., Moya, J., Ibáñez, M. I., ... Fañanás, L. (2014). Psychosis-inducing effects of cannabis are related to both childhood abuse and COMT genotypes. Acta Psychiatrica Scandinavica, 129(1), 54-62.

Amabile, T. M. (1983). The social psychology of creativity: A componential conceptualization. Journal of Personality and Social Psychology, 45(2), 357.

Amabile, T. M., Conti, R., Coon, H., Lazenby, J., \& Herron, M. (1996). Assessing the work environment for creativity. Academy of Management Journal, 39(5), 1154-1184.

Amabile, T. M., \& Pillemer, J. (2012). Perspectives on the Social Psychology of Creativity. The Journal of Creative Behavior, 46(1), 3-15. 
Andreasen, N. C. (1987). Creativity and mental illness: prevalence rates in writers and their first-degree relatives. American Journal of Psychiatry, 144(10), 1288-1292.

Arden, R., Chavez, R. S., Grazioplene, R., \& Jung, R. E. (2010). Neuroimaging creativity: A psychometric view. Behavioural Brain Research, 214(2), 143-156.

BARKóCZI I., OlÁH A. és ZÉTÉNYI T. (1973). Az intelligencia, a kreativitás és a szocio-ökonómiai státusz összefüggéseiről. Magyar Pszichológia Szemle, 30(4), 522-532.

Barrantes-Vidal, N., Chun, C. A., Myin-Germeys, I., \& Kwapil, T. R. (2013). Psychometric schizotypy predicts psychotic-like, paranoid, and negative symptoms in daily life. Journal of Abnormal Psychology, 122(4), 1077-1087.

Barron, F., \& Harrington, D. M. (1981). Creativity, intelligence, and personality. Annual Review of Psychology, 32(1), 439-476.

Batey, M., \& Furnham, A. (2006). Creativity, intelligence, and personality: A critical review of the scattered literature. Genetic, Social, and General Psychology Monographs, 132(4), $355-429$.

Batey, M., \& Furnham, A. (2008). The relationship between measures of creativity and schizotypy. Personality and Individual Differences, 45(8), 816-821.

Beaty, R. E., Silvia, P. J., Nusbaum, E. C., Jauk, E., \& Benedek, M. (2014). The roles of associative and executive processes in creative cognition. Memory and Cognition, 42(7), 1186-1197.

Beauchaine, T. P., Lenzenweger, M. F., \& Waller, N. G. (2008). Schizotypy, taxometrics, and disconfirming theories in soft science. Personality and Individual Differences, 44(8), 1652-1662.

Benedek, M., Jauk, E., Sommer, M., Arendasy, M., \& Neubauer, A. C. (2014). Intelligence, creativity, and cognitive control: The common and differential involvement of executive functions in intelligence and creativity. Intelligence, 46, 73-83.

Benedek, M., \& Neubauer, A. C. (2013). Revisiting Mednick's Model on Creativity-Related Differences in Associative Hierarchies. Evidence for a Common Path to Uncommon Thought. The Journal of Creative Behavior, 47(4), 273-289.

Braunstein-Bercovitz, H., Rammsayer, T., Gibbons, H., \& Lubow, R. E. (2002). Latent inhibition deficits in high-schizotypal normals: symptom-specific or anxiety-related? Schizophrenia Research, 53(1-2), 109-121.

Burch, G. S. J., Hemsley, D. R., Pavelis, C., \& Corr, P. J. (2006). Personality, creativity and latent inhibition. European Journal of Personality, 20(2), 107-122.

Carhart-Harris, R. L., \& Friston, K. J. (2010). The default-mode, ego-functions and free-energy: a neurobiological account of Freudian ideas. Brain, 133(4), 1265-1283.

Cattell, R. B. (1987). Intelligence: Its Structure, Growth and Action: Its Structure, Growth and Action. Amsterdam: Elsevier.

Chmielewski, M., Bagby, R. M., Markon, K., Ring, A. J., \& Ryder, A. G. (2014). Openness to experience, intellect, schizotypal personality disorder, and psychoticism: resolving the controversy. Journal of Personality Disorders, 28(4), 1-17.

Claridge, G., \& Blakey, S. (2009). Schizotypy and affective temperament: Relationships with divergent thinking and creativity styles. Personality and Individual Differences, 46(8), 820-826.

Congdon, E., Lesch, K. P., \& CAnli, T. (2008). Analysis of DRD4 and DAT polymorphisms and behavioral inhibition in healthy adults: implications for impulsivity. American Journal of Medical Genetics Part B: Neuropsychiatric Genetics, 147(1), 27-32. 
Corlett, P. R., \& Fletcher, P. C. (2012). The neurobiology of schizotypy: Fronto-striatal prediction error signal correlates with delusion-like beliefs in healthy people. Neuropsychologia, 50(14), 3612-3620.

Corlett, P. R., Murray, G. K., Honey, G. D., Aitken, M. R. F., Shanks, D. R., Robbins, T. W., ... Fletcher, P. C. (2007). Disrupted prediction-error signal in psychosis: evidence for an associative account of delusions. Brain, 130(9), 2387-2400.

Csíkszentminályi M. (2008). Kreativitás: a flow és a felfedezés, avagy a találékonyság pszichológiája. Budapest: Akadémiai Kiadó.

De Fruyt, F., De Clerce, B., De Bolle, M., Wille, B., Markon, K., \& Krueger, R. F. (2013). General and maladaptive traits in a five-factor framework for DSM-5 in a university student sample. Assessment, 1073191113475808.

De Manzano, Ö., Cervenka, S., Karabanov, A., Farde, L., \& Ullén, F. (2010). Thinking Outside a Less Intact Box: Thalamic Dopamine D2 Receptor Densities Are Negatively Related to Psychometric Creativity in Healthy Individuals. PLoS ONE, 5(5), e10670.

Derks, E. M., Allardyce, J., Boks, M. P., Vermunt, J. K., Hijman, R., \& Ophoff, R. A. (2012). Kraepelin Was Right: A Latent Class Analysis of Symptom Dimensions in Patients and Controls. Schizophrenia Bulletin, 38(3), 495-505.

DeYoung, C. G. (2014). Cybernetic Big Five Theory. Journal of Research in Personality. http://doi.org/10.1016/j.jrp.2014.07.004

DeYoung, C. G., Cicchetti, D., Rogosch, F. A., Gray, J. R., Eastman, M., \& GRIGORENKO, E. L. (2011). Sources of cognitive exploration: Genetic variation in the prefrontal dopamine system predicts Openness/Intellect. Journal of Research in Personality, 45(4), 364-371.

DeYoung, C. G., Grazioplene, R. G., \& Peterson, J. B. (2012). From madness to genius: The Openness/Intellect trait domain as a paradoxical simplex. Journal of Research in Personality, 46(1), 63-78.

DeYoung, C. G., Peterson, J. B., \& Higgins, D. M. (2005). Sources of Openness/Intellect: Cognitive and Neuropsychological Correlates of the Fifth Factor of Personality. Journal of Personality, 73(4), 825-858.

DeYoung, C. G., Quilty, L. C., Peterson, J. B., \& Gray, J. R. (2014). Openness to experience, intellect, and cognitive ability. Journal of Personality Assessment, 96(1), 46-52.

Dickinson, D., RAmsey, M., \& GOLD, J. (2007). Overlooking the obvious: A meta-analytic comparison of digit symbol coding tasks and other cognitive measures in schizophrenia. Archives of General Psychiatry, 64(5), 532-542.

Dietrich, A. (2004). The cognitive neuroscience of creativity. Psychonomic Bulletin and Review, 11(6), 1011-1026.

Dietrich, A. (2014). The mythconception of the mad genius. Psychopathology, 5, 79.

Dietrich, A., \& Kanso, R. (2010). A review of EEG, ERP, and neuroimaging studies of creativity and insight. Psychological Bulletin, 136(5), 822-848.

Domínguez-Martínez, T., Medina-Pradas, C., Kwapil, T. R., \& Barrantes-Vidal, N. (2014). Relatives? illness attributions mediate the association of expressed emotion with early psychosis symptoms and functioning. Psychiatry Research, 218(1-2), 48-53.

Ettinger, U., Meyhofer, I., Steffens, M., Wagner, M., \& Koutsouleris, N. (2014). Genetics, Cognition, and Neurobiology of Schizotypal Personality: A Review of the Overlap with Schizophrenia. Frontiers in Psychiatry, 5.

http://doi.org/10.3389/fpsyt.2014.00018 
Evans, L. H., Gray, N. S., \& SNOwden, R. J. (2007). A new continuous within-participants latent inhibition task: Examining associations with schizotypy dimensions, smoking status and gender. Biological Psychology, 74(3), 365-373.

Fett, A.-K. J., Viechtbauer, W., Dominguez, M.-G., Penn, D. L., Van Os, J., \& KrabBENDAM, L. (2011). The relationship between neurocognition and social cognition with functional outcomes in schizophrenia: A meta-analysis. Neuroscience and Biobehavioral Reviews, 35(3), 573-588.

Fiorillo, C. D., Tobler, P. N., \& Schultz, W. (2003). Discrete Coding of Reward Probability and Uncertainty by Dopamine Neurons. Science, 299(5614), 1898-1902.

Fletcher, P. C., \& Frith, C. D. (2009). Perceiving is believing: a Bayesian approach to explaining the positive symptoms of schizophrenia. Nature Reviews Neuroscience, 10(1), 48-58.

FOLLEY, B. S., \& PARK, S. (2005). Verbal creativity and schizotypal personality in relation to prefrontal hemispheric laterality: A behavioral and near-infrared optical imaging study. Schizophrenia Research, 80(2-3), 271-282.

Friston, K. (2009). The free-energy principle: a rough guide to the brain? Trends in Cognitive Sciences, 13(7), 293-301.

Furnham, A., \& Bachtiar, V. (2008). Personality and intelligence as predictors of creativity. Personality and Individual Differences, 45(7), 613-617.

Furnham, A., Batey, M., Anand, K., \& Manfield, J. (2008). Personality, hypomania, intelligence and creativity. Personality and Individual Differences, 44(5), 1060-1069.

Fyfe, S., Williams, C., Mason, O. J., \& Pickup, G. J. (2008). Apophenia, theory of mind and schizotypy: Perceiving meaning and intentionality in randomness. Cortex, 44(10), 1316-1325.

Galdos, M., Simons, C., Fernandez-Rivas, A., Wichers, M., Peralta, C., Lataster, T., ... VAN Os, J. (2011). Affectively Salient Meaning in Random Noise: A Task Sensitive to Psychosis Liability. Schizophrenia Bulletin, 37(6), 1179-1186.

Getzels, J. W., \& Jackson, P. W. (1962). Creativity and intelligence: Explorations with gifted students (Vol. xvii). Oxford: Wiley.

Granger, K. T., Prados, J., \& Young, A. M. J. (2012). Disruption of overshadowing and latent inhibition in high schizotypy individuals. Behavioural Brain Research, 233(1), 201208.

Grant, P., Balser, M., Munk, A. J. L., Linder, J., \& Hennig, J. (2014). A False-Positive Detection Bias as a Function of State and Trait Schizotypy in Interaction with Intelligence. Frontiers in Psychiatry, 5. http://doi.org/10.3389/fpsyt.2014.00135

Guilford, J. P. (1950). Creativity. American Psychologist, 5(9), 444-454.

Hori, H., Teraishi, T., Sasayama, D., Matsuo, J., Kinoshita, Y., Ota, M., ... Kunugi, H. (2014). A latent profile analysis of schizotypy, temperament and character in a nonclinical population: Association with neurocognition. Journal of Psychiatric Research, 48(1), 56-64.

Howes, O. D., \& Kapur, S. (2009). The Dopamine Hypothesis of Schizophrenia: Version III - The Final Common Pathway. Schizophrenia Bulletin, 35(3), 549-562.

JANKa Z. (2006). Hangulatzavarok befolyása a kreativitásra. Ideggyógyászati Szemle, 59(7-8), 236-240. 
Jauk, E., Benedek, M., Dunst, B., \& Neubauer, A. C. (2013). The relationship between intelligence and creativity: New support for the threshold hypothesis by means of empirical breakpoint detection. Intelligence, 41(4), 212-221.

Jauk, E., Benedek, M., \& Neubauer, A. C. (2013). The Road to Creative Achievement: A Latent Variable Model of Ability and Personality Predictors: The road to creative achievement. European Journal of Personality, 28(1), 95-105.

JUNG, R. E. (2014). Evolution, creativity, intelligence, and madness:"Here Be Dragons." Frontiers in Psychology, 5.

Retrieved from http://www.ncbi.nlm.nih.gov/pmc/articles/PMC4107956/

KARLSSON, J. L. (1970). Genetic association of giftedness and creativity with schizophrenia. Hereditas, 66(2), 177-181.

Kaufman, J. C., \& Beghetto, R. A. (2009). Beyond big and little: The four c model of creativity. Review of General Psychology, 13(1), 1.

KÉRI, S. (2011). Solitary minds and social capital: Latent inhibition, general intellectual functions and social network size predict creative achievements. Psychology of Aesthetics, Creativity, and the Arts, 5(3), 215-221.

KÉRI Sz. (2013). Lágy lélektani és szociológiai tényezők egy kemény pszichiátriai betegség hátterében: a szkizofrénia rejtélye. Magyar Pszichológiai Szemle, 68(1), 127-140.

King, L. A., Walker, L. M., \& Broyles, S. J. (1996). Creativity and the Five-Factor Model. Journal of Research in Personality, 30(2), 189-203.

KŐVÁRY Z. (2012). Látomás és indulat a képzőművészetben - Csontváry és a kreativitás a mai pszichobiográfia tükrében. Imágó Budapest, 2(1), 35-61.

Krueger, R. F., \& Markon, K. E. (2014). The Role of the DSM-5 Personality Trait Model in Moving Toward a Quantitative and Empirically Based Approach to Classifying Personality and Psychopathology. Annual Review of Clinical Psychology, 10(1), 477-501.

Kyaga, S., Landén, M., Boman, M., Hultman, C. M., LÅngström, N., \& Lichtenstein, P. (2013). Mental illness, suicide and creativity: 40-Year prospective total population study. Journal of Psychiatric Research, 47(1), 83-90.

Kyaga, S., Lichtenstein, P., Boman, M., Hultman, C., LÅngström, N., \& Landén, M. (2011). Creativity and mental disorder: family study of 300000 people with severe mental disorder. The British Journal of Psychiatry, 199(5), 373-379.

Laurens, K. R., Hobbs, M. J., Sunderland, M., Green, M. J., \& Mould, G. L. (2012). Psychotic-like experiences in a community sample of 8000 children aged 9 to 11 years: an item response theory analysis. Psychological Medicine, 42(07), 1495-1506.

LEE, J., \& PARK, S. (2005). Working memory impairments in schizophrenia: a metaanalysis. Journal of Abnormal Psychology, 114(4), 599.

Lin, W.-L., \& LiEN, Y.-W. (2013). Exploration of the relationships between retrievalinduced forgetting effects with open-ended versus closed-ended creative problem solving. Thinking Skills and Creativity, 10, 40-49.

Lubow, R. E. (2005). Construct Validity of the Animal Latent Inhibition Model of Selective Attention Deficits in Schizophrenia. Schizophrenia Bulletin, 31(1), 139-153.

MacCabe, J. H., Lambe, M. P., Cnattingius, S., Sham, P. C., David, A. S., Reichenberg, A., ... Hultman, C. M. (2010). Excellent school performance at age 16 and risk of adult bipolar disorder: national cohort study. The British Journal of Psychiatry, 196(2), 109-115. 
Markon, K. E., Chmielewski, M., \& Miller, C. J. (2011). The reliability and validity of discrete and continuous measures of psychopathology: A quantitative review. Psychological Bulletin, 137(5), 856-879.

Mason, O., \& Claridge, G. (2006). The Oxford-Liverpool Inventory of Feelings and Experiences (O-LIFE): Further description and extended norms. Schizophrenia Research, 82(2-3), 203-211.

Mayseless, N., Uzefovsky, F., Shalev, I., Ebstein, R. P., \& Shamay-Tsoory, S. G. (2013). The association between creativity and $7 \mathrm{R}$ polymorphism in the dopamine receptor $\mathrm{D} 4$ gene (DRD4). Frontiers in Human Neuroscience, 7. http://doi.org/10.3389/fnhum.2013.00502

Mednick, S. (1962). The associative basis of the creative process. Psychological Review, 69(3), 220.

Mesholam-Gately, R. I., Giuliano, A. J., Goff, K. P., Faraone, S. V., \& Seidman, L. J. (2009). Neurocognition in first-episode schizophrenia: a meta-analytic review. Neuropsychology, 23(3), 315 .

Miller, G. F., \& TAL, I. R. (2007). Schizotypy versus openness and intelligence as predictors of creativity. Schizophrenia Research, 93(1-3), 317-324.

Nagy, H., Levy-Gigi, E., Somlai, Z., Takáts, A., Bereczki, D., \& Kéri, S. (2012). The Effect of Dopamine Agonists on Adaptive and Aberrant Salience in Parkinson's Disease. Neuropsychopharmacology, 37(4), 950-958.

Nelson, B., \& Rawlings, D. (2010). Relating Schizotypy and Personality to the Phenomenology of Creativity. Schizophrenia Bulletin, 36(2), 388-399.

Nelson, B., Whitford, T. J., Lavoie, S., \& SASs, L. A. (2014). What are the neurocognitive correlates of basic self-disturbance in schizophrenia?: Integrating phenomenology and neurocognition: Part 2 (Aberrant salience). Schizophrenia Research, 152(1), 20-27.

Nelson, M. T., Seal, M. L., Pantelis, C., \& Phillips, L. J. (2013). Evidence of a dimensional relationship between schizotypy and schizophrenia: A systematic review. Neuroscience and Biobehavioral Reviews, 37(3), 317-327.

Nettle, D., \& ClegG, H. (2006). Schizotypy, creativity and mating success in humans. Proceedings of the Royal Society B: Biological Sciences, 273(1586), 611-615.

Nowakowska, C., Strong, C. M., Santosa, C. M., Wang, P. W., \& Ketter, T. A. (2005). Temperamental commonalities and differences in euthymic mood disorder patients, creative controls, and healthy controls. Journal of Affective Disorders, 85(1-2), 207-215.

Pessiglione, M., Seymour, B., Flandin, G., Dolan, R. J., \& Frith, C. D. (2006). Dopamine-dependent prediction errors underpin reward-seeking behaviour in humans. $\mathrm{Na}$ ture, 442(7106), 1042-1045.

Peterson, J. B., \& Carson, S. (2000). Latent Inhibition and Openness to Experience in a high-achieving student population. Personality and Individual Differences, 28(2), 323-332.

Peterson, J. B., Smith, K. W., \& CARson, S. (2002). Openness and extraversion are associated with reduced latent inhibition: replication and commentary. Personality and Individual Differences, 33(7), 1137-1147.

PLÉH Cs. (2010). Kreativitás, tehetség és gyakorlás: hangsúlyváltások a kutatásban. Magyar Pszichológiai Szemle, 65(2), 199-220.

Plucker, J. A., Beghetto, R. A., \& Dow, G. T. (2004). Why isn't creativity more important to educational psychologists? Potentials, pitfalls, and future directions in creativity research. Educational Psychologist, 39(2), 83-96. 
RAWlingS, D., \& Locarnini, A. (2008). Dimensional schizotypy, autism, and unusual word associations in artists and scientists. Journal of Research in Personality, 42(2), 465-471.

Rawlings, D., Williams, B., Haslam, N., \& Claridge, G. (2008a). Is schizotypy taxonic? Response to Beauchaine, Lenzenweger, and Waller. Personality and Individual Differences, 44(8), 1663-1672.

Rawlings, D., Williams, B., Haslam, N., \& Claridge, G. (2008b). Taxometric analysis supports a dimensional latent structure for schizotypy. Personality and Individual Differences, 44(8), 1640-1651.

Reed, P., Wakefield, D., Harris, J., Parry, J., Cella, M., \& Tsakanikos, E. (2008). Seeing non-existent events: Effects of environmental conditions, schizotypal symptoms, and sub-clinical characteristics. Journal of Behavior Therapy and Experimental Psychiatry, 39(3), 276-291.

Reuter, M., Roth, S., Holve, K., \& Hennig, J. (2006). Identification of first candidate genes for creativity: A pilot study. Brain Research, 1069(1), 190-197.

Richards, R., Kinney, D. K., Lunde, I., Benet, M., \& Merzel, A. P. C. (1988). Creativity in manic-depressives, cyclothymes, their normal relatives, and control subjects. Journal of Abnormal Psychology, 97(3), 281-288.

Rihmer Z., Gonda X. és Rihmer A. (2006). Kreativitás és pszichiátriai betegségek. Psychiatria Hungarica, 21, 288-294.

Ritchie, T., \& Noble, E. P. (2003). Association of Seven Polymorphisms of the D2 Dopamine Receptor Gene with Brain Receptor-Binding Characteristics. Neurochemical Research, 28(1), 73-82.

Roiser, J. P., Stephan, K. E., den Ouden, H. E. M., Barnes, T. R. E., Friston, K. J., \& JOYCE, E. M. (2009). Do patients with schizophrenia exhibit aberrant salience? Psychological Medicine, 39(02), 199-209.

Runco, M. A., \& ACAR, S. (2012). Divergent Thinking as an Indicator of Creative Potential. Creativity Research Journal, 24(1), 66-75.

Runco, M. A., \& Jaeger, G. J. (2012). The Standard Definition of Creativity. Creativity Research Journal, 24(1), 92-96.

SChlesinger, J. (2009). Creative mythconceptions: A closer look the evidence for the "mad genius" hypothesis. Psychology of Aesthetics, Creativity, and the Arts, 3(2), 62.

SCHMidt, K., \& RoISER, J. P. (2009). Assessing the construct validity of aberrant salience. Frontiers in Behavioral Neuroscience, 3, 58.

Schofield, K., \& Claridge, G. (2007). Paranormal experiences and mental health: Schizotypy as an underlying factor. Personality and Individual Differences, 43(7), 1908-1916.

SCHultz, W. (2000). Multiple reward signals in the brain. Nature Reviews Neuroscience, 1(3), 199-207.

Silvia, P. J., Beaty, R. E., \& Nusbaum, E. C. (2013). Verbal fluency and creativity: General and specific contributions of broad retrieval ability (Gr) factors to divergent thinking. Intelligence, 41(5), 328-340.

Silvia, P. J., Nusbaum, E. C., Berg, C., Martin, C., \& O'Connor, A. (2009). Openness to experience, plasticity, and creativity: Exploring lower-order, high-order, and interactive effects. Journal of Research in Personality, 43(6), 1087-1090. 
Silvia, P. J., Winterstein, B. P., Willse, J. T., Barona, C. M., Cram, J. T., Hess, K. I., ... RichaRD, C. A. (2008). Assessing creativity with divergent thinking tasks: Exploring the reliability and validity of new subjective scoring methods. Psychology of Aesthetics, Creativity, and the Arts, 2(2), 68-85.

Simeonova, D. I., Chang, K. D., Strong, C., \& Ketter, T. A. (2005). Creativity in familial bipolar disorder. Journal of Psychiatric Research, 39(6), 623-631.

Simmonds-Moore, C. (2014). Exploring the perceptual biases associated with believing and disbelieving in paranormal phenomena. Consciousness and Cognition, 28, 30-46.

Simonton, D. K. (2000). Creativity: Cognitive, personal, developmental, and social aspects. American Psychologist, 55(1), 151.

SMith, A., LI, M., Becker, S., \& KAPUR, S. (2006). Dopamine, prediction error and associative learning: A model-based account. Network: Computation in Neural Systems, 17(1), 6184.

Soliman, A., O’Driscoll, G. A., Pruessner, J., Holahan, A.-L. V., Boileau, I., Gagnon, D., \& Dagher, A. (2008). Stress-Induced Dopamine Release in Humans at Risk of Psychosis: a [ 11C] Raclopride PET Study. Neuropsychopharmacology, 33(8), 2033-2041.

Soliman, A., O’Driscoll, G. A., Pruessner, J., Joober, R., Ditto, B., Streicker, E., ... DAGHER, A. (2011). Limbic response to psychosocial stress in schizotypy: A functional magnetic resonance imaging study. Schizophrenia Research, 131(1-3), 184-191.

STERnBERG, R. J. (2001). What is the common thread of creativity? Its dialectical relation to intelligence and wisdom. American Psychologist, 56(4), 360.

Swerdlow, N. R., Stephany, N., Wasserman, L. C., Talledo, J., Sharp, R., \& Auerbach, P. P. (2003). Dopamine agonists disrupt visual latent inhibition in normal males using a within-subject paradigm. Psychopharmacology, 169(3-4), 314-320.

TAit, L., Birchwood, M., \& Trower, P. (2004). Adapting to the challenge of psychosis: personal resilience and the use of sealing-over (avoidant) coping strategies. The British Journal of Psychiatry, 185(5), 410-415.

Takeuchi, H., Taki, Y., Sassa, Y., Hashizume, H., Sekiguchi, A., Fukushima, A., \& KaWASHIMA, R. (2010). Regional gray matter volume of dopaminergic system associate with creativity: Evidence from voxel-based morphometry. NeuroImage, 51(2), 578-585.

Thomas, K. M., Yalch, M. M., Krueger, R. F., Wright, A. G. C., Markon, K. E., \& Hopwood, C. J. (2013). The Convergent Structure of DSM-5 Personality Trait Facets and Five-Factor Model Trait Domains. Assessment, 20(3), 308-311.

Tsakanikos, E. (2006). Perceptual biases and positive schizotypy: The role of perceptual load. Personality and Individual Differences, 41(5), 951-958.

Tsakanikos, E., \& ReED, P. (2004). Latent inhibition and context change in psychometrically defined schizotypy. Personality and Individual Differences, 36(8), 1827-1839.

TSAKAnikos, E., \& REED, P. (2005). Do positive schizotypal symptoms predict false perceptual experiences in nonclinical populations? The Journal of Nervous and Mental Disease, 193(12), 809-812.

Tsakanikos, E., Sverdrup-Thygenson, L., \& Reed, P. (2003). Latent inhibition and psychosis-proneness: visual search as a function of pre-exposure to the target and schizotypy level. Personality and Individual Differences, 34(4), 575-589. 
Van Os, J., Linscott, R. J., Myin-Germeys, I., Delespaul, P., \& Krabbendam, L. (2008). A systematic review and meta-analysis of the psychosis continuum: evidence for a psychosis proneness-persistence-impairment model of psychotic disorder. Psychological Medicine, 39(02), 179.

Weiner, I., \& ARAD, M. (2009). Using the pharmacology of latent inhibition to model domains of pathology in schizophrenia and their treatment. Behavioural Brain Research, 204(2), 369-386.

White, H. A., \& SHAH, P. (2006). Uninhibited imaginations: Creativity in adults with Attention-Deficit/Hyperactivity Disorder. Personality and Individual Differences, 40(6), 1121 1131.

White, H. A., \& SHAH, P. (2011). Creative style and achievement in adults with attentiondeficit/hyperactivity disorder. Personality and Individual Differences, 50(5), 673-677.

Zabelina, D. L., Condon, D., \& Beeman, M. (2014). Do dimensional psychopathology measures relate to creative achievement or divergent thinking? Frontiers in Psychology, 5. http://doi.org/10.3389/fpsyg.2014.01029

Zabelina, D. L., \& Robinson, M. D. (2010). Creativity as flexible cognitive control. Psychology of Aesthetics, Creativity, and the Arts, 4(3), 136.

\title{
INDIVIDUAL DIFFERENCES IN CREATIVE THINKING: PSYCHOTIC-LIKE FEATURES IN AN ADAPTIVE CONTEXT?
}

\author{
POLNER, BERTALAN - KÉRI, SZABOLCS
}

Rationale: Creativity can be related to the continuum between psychotic disorders and normality. Schizotypal traits, that is, personality traits resembling the positive, negative, disorganized and affective symptoms of schizophrenia, have been associated with creative potential and achievement in healthy populations. How can we explain these relationships at the level of fundamental cognitive processes? What are the other individual differences relevant to creativity?

Method: We reviewed studies that investigated creativity either in the context of the psychosis spectrum or in relationship with personality traits, cognitive abilities, and social context. Additionally, studies examining potential neural correlates of creativity were discussed in the review.

Results: Reduced latent inhibition, atypical pattern perception and aberrant salience are some neurocognitive features characterizing the psychosis spectrum which might provide a link between schizotypy and creativity. Dopaminergic involvement has been assumed in all of these functions. On the other hand, a substantial part of the empirical literature underscored the crucial role of openness, high intelligence and intact executive functioning in creative thinking and achievement. Additional studies highlighted the importance of social support in the creative process.

Conclusions: The reviewed literature suggests that the neurocognitive structure of schizotypy, when accompanied by adaptive factors, can subserve creativity. The precise nature of the relationship between the features and the development of adaptive schizotypy and openness remains to be clarified.

Key words: creativity, psychosis, openness, dopamine, intelligence 